\title{
THE FIRST EUROPEAN RECORD OF THE INDONESIAN SNAKEHEAD, CHANNA MICROPELTES (ACTINOPTERYGII: PERCIFORMES: CHANNIDAE)
}

\author{
Sandro PIAZZINI, Ioannis SEGOS, Leonardo FAVILLI * , and Giuseppe MANGANELLI \\ Department of Physical Sciences, Earth and Environment, University of Siena, Italy
}

Piazzini S., Segos I., Favilli L., Manganelli G. 2014. The first European record of the Indonesian snakehead, Channa micropeltes (Actinopterygii: Perciformes: Channidae). Acta Ichthyol. Piscat. 44 (2): $153-155$.

\begin{abstract}
A specimen of Indonesian snakehead, Channa micropeltes (Cuvier, 1831), $76.5 \mathrm{~cm}$ long (TL) and weighing $5.8 \mathrm{~kg}$, was caught on 22 November 2012 in a small pool fed by a subthermal spring at Le Caldane (Colle di Val d'Elsa, Siena, Tuscany, Italy). This catch constitutes the first record of C. micropeltes in Europe.
\end{abstract}

Keywords: Tuscany, Italy, alien species

The Indonesian snakehead, Channa micropeltes (Cuvier, 1831) (Perciformes: Channidae) is a large predatory fish (up to $150 \mathrm{~cm}$ in length and $20 \mathrm{~kg}$ in weight), native to southeast Asia, where it occurs in Thailand, Vietnam, Malaysia, Laos, and Indonesia (Java, Sumatra, Borneo, Belitung, Bangka). It has also been reported from India, but the taxonomic identity of Indian specimens is still controversial (Courtenay and Williams 2004, Adamson et al. 2010, Benziger et al. 2011, Froese and Pauly 2013). It inhabits lakes, slow-flowing rivers and canals with deep, well vegetated water, and the temperatures between 25 and $28^{\circ} \mathrm{C}$. The spawning occurs in November and December and females spawn 2000-3000 eggs, which are protected by the male. The juveniles feed on crustaceans. Adults are mainly piscivorous, but also feed on other vertebrates, hunting in packs during the day, mainly near the surface or in midwater (Courtenay and Williams 2004, Froese and Pauly 2013).

Channa micropeltes was introduced and became established in Singapore in the second half of the 20th century. It was also introduced into China, the Philippines and the United States (Maine, Maryland, Massachusetts, Rhode Island, and Wisconsin) but did not become established. In spite of this it is regarded a major threat to the native fish fauna (Courtenay and Williams 2004, Joshi 2006, Pegg et al. 2009) and trading this fish is prohibited in many US states (Courtenay and Williams 2004). Adults are raised in water cages as food in Vietnam, Malaysia, Thailand, and Cambodia, whereas juveniles, which are red with two dark stripes on each side, are sold for aquaria (Courtenay and Williams 2004, Froese and Pauly 2013).
An adult specimen of Channa micropeltes was captured on 22 November 2012 at Le Caldane (Colle di Val d'Elsa, Siena, Tuscany, Italy) $\left(43^{\circ} 23^{\prime} 26.67^{\prime \prime} \mathrm{N}, 11^{\circ} 08^{\prime} 04.23^{\prime \prime} \mathrm{E}\right)$. Le Caldane is a small pool fed by a subthermal spring (temperature near the source $22.6^{\circ} \mathrm{C}$; average annual pool temperature $21.4^{\circ} \mathrm{C}$; average flow $80 \mathrm{~L} \cdot \mathrm{s}^{-1}$; Ca $303 \mathrm{mg} \cdot \mathrm{L}^{-1}$; $\mathrm{Mg} 82 \cdot 7 \mathrm{mg} \cdot \mathrm{L}^{-1}$; and $\mathrm{SO}_{4} 690 \mathrm{mg} \cdot \mathrm{L}^{-1}$ ) which gives rise to a small creek that flows into the Elsa river (the Arno River basin) (Barazzuoli and Salleolini 1993, Peruzzi and Mantelli 2003).

The specimen of Channa micropeltes (Fig. 1) was captured with a pulsed direct current (DC) $(350-600 \mathrm{~V}$, $12 \mathrm{~kW}, 0-100$ impulses per second) and was identified according to Musikasinthorn and Taki (2001) and Courtenay and Williams (2004). The fish was $76.5 \mathrm{~cm}$ long (TL) and weighed $5.8 \mathrm{~kg}$.

Short description. Dorsal part grey; flanks brown tending to grey; abdominal parts grey; head length $36.9 \%$ of SL; maxilla reaching beyond posterior border of the eye; lower jaw with several rows of canine-like teeth behind single row of villi-like teeth; large canine-like teeth on prevomer and palatines; scales in gular area; 22 predorsal scales; 23 cheek scales; 90 scales in longitudinal series; 44 dorsal fin rays; 28 anal fin rays; 15 pectoral fin rays; 6 pelvic fin rays.

The specimen is kept in the fish collection of the Museo di Storia Naturale dell'Accademia dei Fisiocritici di Siena (Siena, Italy).

This record of Channa micropeltes, the first in Europe, and it constitutes another case of introduction of an alien species. Globally, exotic fish are a major threat to

\footnotetext{
${ }^{*}$ Correspondence: Dr. Leonardo Favilli, Dipartimento di Scienze Fisiche della Terra e dell'Ambiente, Università di Siena, Siena, Italy, phone: +390577232920 ,
} fax: +390577232860, e-mail: (LF) leonardo.favilli@unisi.it, (PS) piazzini5@unisi.it, (IS) iannothebest.90@libero.it, (GM) giuseppe.manganelli@unisi.it. 


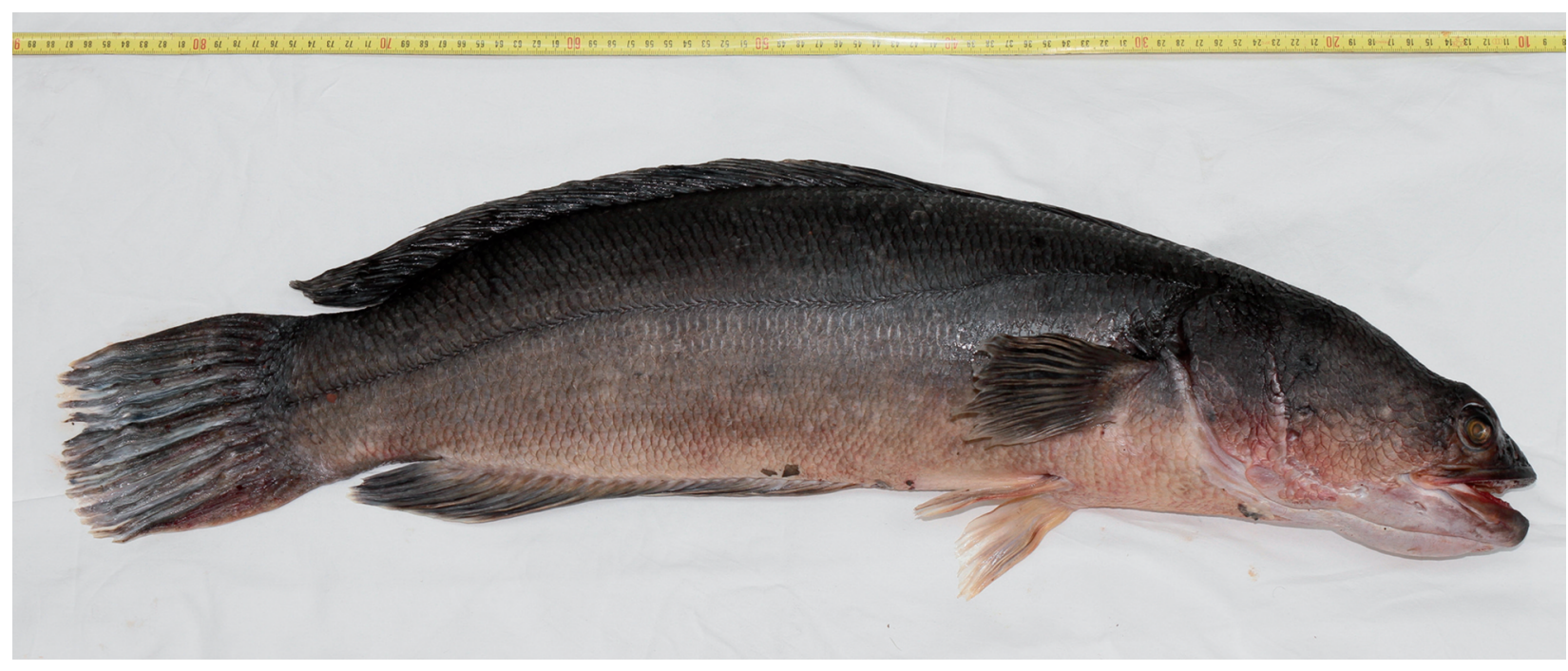

Fig. 1. Indonesian snakehead, Channa micropeltes, captured on 22 November 2012 at Le Caldane (Tuscany, Italy)

native ichthyofauna due to their negative impact on local species (Crivelli 1995, Elvira 2001, Smith and Darwall 2006, Gozlan et al. 2010, Hermoso and Clavero 2011).

One way in which alien fish colonize new geographic areas is through the aquarium trade. Aquarium enthusiasts often release their pet fishes into nature when they grow too big to be kept at home (Rixon et al. 2005, Duggan et al. 2006, Gozlan 2008, Duggan 2010, Savini et al. 2010, Keller et al. 2011). Channa micropeltes almost certainly appeared at Le Caldane in this way, since channids are bred for aquaria even in Italy.

So far only one specimen of Channa micropeltes has been caught at Le Caldane, but others may be present. Although no data is available, the size of this specimen suggests that it was released some time ago. It is also possible that the disappearance of two cyprinid species of conservation concern, present at Le Caldane until recently (at least until 2010), Rutilus rubilio (Bonaparte, 1837) and Tinca tinca (Linnaeus, 1758), is related to the presence of $C$. micropeltes.

\section{REFERENCES}

Adamson E.A.S., Hurwood D.A., Mather P.B. 2010. A reappraisal of the evolution of Asian snakehead fishes (Pisces, Channidae) using molecular data from multiple genes and fossil calibration. Molecular Phylogenetics and Evolution 56 (2): 707-717. DOI: 10.1016/j.ympev.2010.03.027

Barazzuoli P., Salleolini M. 1993. L'acqua: risorsa, rischio e pianificazione. [Water: resource, risk, and planning.] Pp. 173-246. In: Giusti F. (ed.) La Storia naturale della Toscana meridionale. [The natural history of southern Tuscany.] Amilcare Pizzi Editore, Cinisello Balsamo, Milano. [In Italian.]

Benziger A., Philip S., Raghavan R., Anvar Ali P.H., Sukumaran M., Tharian J.C., Dahanukar N., Baby F., Peter R., Rema Devi K., Radhakrishnan K.V., Haniffa M.A., Britz R., Antunes A. 2011. Unraveling 146 years old taxonomic puzzle: validation of Malabar snakehead, species status and its relevance for Channid systematics and evolution.
PloS ONE 6 (6): e21272. DOI: 10.1371/journal.pone. 0021272

Courtenay W.R. jr., Williams J.D. 2004. Snakeheads (Pisces, Channidae)-A biological synopsis and risk assessment. U.S. Geological Survey, Circular No. 1251.

Crivelli A.J. 1995. Are fish introductions a threat to endemic freshwater fishes in the northern Mediterranean region? Biological Conservation 72 (2): 311-319. DOI: 10.1016/ 0006-3207(94)00092-5

Duggan I.C. 2010. The freshwater aquarium trade as a vector for incidental invertebrate fauna. Biological Invasions 12 (11): 3757-3770. DOI: 10.1007/s10530-010-9768-x

Duggan I.C., Rixon C.A.M., McIsaac H.J. 2006. Popularity and propagule pressure: determinants of introduction and establishment of aquarium fish. Biological Invasions 8 (2): 377-382. DOI: $10.1007 / \mathrm{s} 10530-004-2310-2$

Elvira B. 2001. Identification of non-native freshwater fishes established in Europe and assessment of their potential threats to the biological diversity. Convention on the Conservation of European Wildlife and Natural Habitats, Standing Committee, 21st meeting Strasbourg, 26-30 November 2001, T-PVS (2001) 6.

Froese R., Pauly D. (eds.) 2013. FishBase. [version 12/2013] http://www.fishbase.org

Gozlan R.E. 2008. Introduction of non-native freshwater fish: is it all bad? Fish and Fisheries 9 (1): 106-115. DOI: 10.1111/j.1467-2979.2007.00267.x

Gozlan R.E., Britton J.R., Cowx I., Copp G.H. 2010. Current knowledge on non-native freshwater fish introduction. Journal of Fish Biology 76 (4): 751-786. DOI: 10.1111/j.1095-8649.2010.02566.x

Hermoso V., Clavero M. 2011. Threatening processes and conservation management of endemic freshwater fish in the Mediterranean basin: a review. Marine and Freshwater Research 62 (3): 244-254. DOI: 10.1071/MF09300

Joshi R.C. 2006. Invasive alien species (IAS): concerns and status in the Philippines. Pp. 11-1-11-23. In: Chiang M.-Y., Ku T.-Y. (eds.) Proceedings of International Workshop on 
Development of Database (APASD) for Biological Invasion. 18-22 September 2006, Taichung, Taiwan; Taiwan Agricultural Chemicals and Toxic Substance Research Institute, Taichung, Taiwan.

Keller R.P., Geist J., Jeschke J.M., Kühn I. 2011. Invasive species in Europe: ecology, status and policy. Environmental Sciences Europe 23: 23. DOI: 10.1186/21904715-23-23

Musikasinthorn P., Taki Y. 2001. Channa siamensis (Günther, 1861), a junior synonym of Channa lucius (Cuvier in Cuvier and Valenciennes, 1831). Ichthyological Research 48 (3): 319-324. DOI: 10.1007/s10228-001-8153-2

Pegg M.A., Chick J.H., Pracheil B.M. 2009. Potential effects of invasive species on paddlefish. Pp. 185-201. In: Paukert C., Scholten G. (eds.) Paddlefish management, propagation, and conservation in the 21st century: Building from 20 years of research and management. American Fisheries Society Symposium 66, Bethesda, MD, USA.

Peruzzi P., Mantelli F. 2003. Il territorio della Valdelsa e le sue acque: verso una conoscenza integrata per la tutela delle risorse idriche. [The Valdelsa and its water: towards an inte- grated knowledge for the protection of water resources.] Agenzia regionale per la protezione ambientale della Toscana, Firenze. [In Italian.]

Rixon C.A.M., Duggan I.C., Bergeron N.M.N., Ricciardi A., MacIsaac H.J. 2005. Invasion risks posed by the aquarium trade and live fish markets on the Laurentian Great Lakes. Biodiversity and Conservation 14 (6): 1365-1381. DOI: 10.1007/s10531-004-9663-9

Savini D., Occhipinti-Ambrogi A., Marchini A., Tricarico E., Gherardi F., Olenin S., Gollasch S. 2010. The top 27 animal alien species introduced into Europe for aquaculture and related activities. Journal of Applied Ichthyology 26 (Suppl. s2): 1-7. DOI: 10.1111/j.1439-0426.2010.01503.x

Smith K., Darwall W.R.T. (eds.) 2006. The status and distribution of freshwater fish endemic to the Mediterranean Basin. IUCN, Gland and Cambridge.

Received: 25 July 2013 Accepted: 19 February 2014 Published electronically: 30 June 2014 